\title{
Rapid and Efficient BAC Recombineering: Gain \& Loss Screening System
}

Running title: Rapid and Efficient BAC Recombineering

Myeong Uk Kuk ${ }^{1}$, Sekyung $\mathrm{Oh}^{2,3, *}$, Joon Tae Park ${ }^{1, *}$

${ }^{1}$ Division of Life Sciences, College of Life Sciences and Bioengineering, Incheon National University, Incheon, Korea

${ }^{2}$ Department of Medicine, Catholic Kwandong University College of Medicine, Incheon, Korea

${ }^{3}$ Institute for Biomedical Research, Catholic Kwandong University International St. Mary's Hospital, Incheon, Korea,

*Correspondence to:

Sekyung Oh, Ph.D.

Department of Medicine

Catholic Kwandong University College of Medicine

Incheon, Korea

Tel: $+82-10-6562-7585$

E-mail: ohskjhmi@ish.ac.kr

Joon Tae Park, Ph.D.

Division of Life Sciences

College of Life Sciences and Bioengineering

Incheon National University

Incheon, Korea

Tel: +82-32-835-8841

E-mail: joontae.park@inu.ac.kr 


\begin{abstract}
Recombineering has been developed to modify bacterial artificial chromosome (BAC) via homologous recombination. Nevertheless, as a screening strategy to identify the correct clone was not properly developed, it was difficult to obtain a correct clone within a limited time period. To address these issues, we developed a new screening method (a gain \& loss screening system) that enables the efficient identification of the recombineered clone. Simple inoculation of cells into LB medium with appropriate antibiotics visually revealed the positive clones within $24 \mathrm{~h}$. DNA sequencing confirmed $100 \%$ accuracy of this screening method by showing that all positive clones exhibited recombinant sequences. Furthermore, our new method allowed us to complete the entire procedure consisting of $1^{\text {st }}$ recombineering, flip-out and $2^{\text {nd }}$ recombineering in just 13 days. Overall, our new strategy may provide a new avenue for BAC recombeerining, as evidenced by markedly increased accuracy and subsequently shortened recombineering duration.
\end{abstract}

Keywords: recombineering $\bullet$ lamda-red recombinase $\bullet$ gain \& loss screening system 


\section{INTRODUCTION}

The production of biopharmaceutical proteins has been a key topic in biotechnology with mammalian cell culture being a widely used method for their production (Wurm 2004). Currently, over 100 therapeutic proteins are being produced in mammalian systems, and their number is expected to increase dramatically as new therapeutic antibodies are developed (Rita Costa et al. 2010). Thus, significant efforts have been made in the last decades to improve protein production in mammalian cell lines. Plasmid-based vectors are the most widely used tools for protein production. They include promoters that induce the expression of gene-of-interest (GOI). However, expression of GOI in plasmid-based vectors is greatly affected by surrounding chromatin at the integration site. Once the vector is integrated into a "silent chromatin" region, the expression tends to silence over time (i.e., positional chromatin effects) (Giraldo and Montoliu 2001). Accordingly, several strategies have been developed to avoid the local effects of chromatin. One of the most widely used methods is to use bacterial artificial chromosome (BAC) that can accommodate whole mammalian loci. BAC can accommodate a complete gene containing all cis-acting regulatory elements in their native configuration. Therefore, BAC is minimally affected by the surrounding chromatin at the integration site, so BAC can accurately deliver the expected expression pattern (Giraldo and Montoliu 2001).

Nevertheless, since the BAC size is very large, their modification cannot be made using standard cloning procedures (e.g., restriction enzyme digestion or ligation). BAC recombineering only allows the exchange of genetic information between two DNA molecules in an accurate, specific, and faithful way, regardless of the size of the DNA. However, BAC recombineering is very labor-intensive and time-consuming due to a large number of false positive background colonies during screening procedure. Therefore, BAC recombineering constituted a substantial barrier for less experienced researchers to consider BAC suitable as expression vectors for protein production.

Here we present a new screening method, the gain \& loss screening system, which can provide markedly increased accuracy and shortened working time. This new strategy may provide powerful new tool for facilitating e.g. biopharmaceutical protein expression and other largevector applications, and rendering such approaches feasible for less experienced laboratories. 


\section{MATERIALS AND METHODS}

\section{Bacterial strain and BAC clones}

SW105 bacteria: Genotype F-mcrA $4(m r r-h s d \mathrm{RMS}-m c r \mathrm{BC})$ (80dlacZ M15 AlacX74 deoR recA1 end 1 1 araD139 $\Delta($ ara, leu $) 7649$ galU galK rspL nup $[\lambda$ cl857 (cro-bioA) $<>$ tet $][($ crobioA) $<$ araC-PBADflpe]. SW105 bacteria was generously provided by the Copeland laboratory at the National Cancer Institute. BAC clone (RP24-85L15) was purchased from BACPAC resources center (CHORI, Oakland, CA, USA).

\section{Preparation of BAC targeting cassette (BTC) and chloramphenicol (Cam) targeting cassette (CTC)}

BAC targeting vector (BTV) (Addgene, cat. no. 131589) and Cam targeting cassette (CTV) (Addgene, cat. no. 131590) are available from Addgene. Incubate BTV with XhoI \& XmaI and $\mathrm{CTV}$ with BamHI \& XhoI for $4 \mathrm{~h}$ at $37^{\circ} \mathrm{C}$. Load the digested DNA onto a $0.2 \%$ agarose gel. Run the gel for $30 \mathrm{~min}$ at $100 \mathrm{~V}$ on a DNA electrophoresis device (Bioand, cat. no. Mini-ES). Following electrophoresis, cut out the DNA band containing the BTC and CTC under a LED trans illuminator (Maestrogen, cat. no. SLB-01W). Purify the DNA using a gel extraction kit (Qiagen, cat. no. 28704). Measure the DNA concentration using Nanodrop spectrophotometer (Denovix, cat. no. DS-11) and dilute the DNA to 8-10 ng/ $\mu$ l using DW.

\section{Overview of the procedure}

The comprehensive details on the methodology is describe in the Supplementary Material. To provide comprehensive details on the methodology, we have organized the $\mathrm{BAC}$ recombineering process into five consecutive stages, which are illustrated in a general flow-chart (Supplementary Fig. 1). In the first stage (steps 1-8), the identification of the desired BAC and the preparation of SW105 bacteria containing the BAC was performed. In the second stage (steps $9-15$ ), the $1^{\text {st }}$ recombineering was conducted to introduce a BTC into the predetermined region of BAC. In the third stage (steps 16-18), flip-out was conducted to delete the selection marker, kanamycin resistance (KanR) gene. In the fourth stage (steps 19-23), the $2^{\text {nd }}$ recombineering was conducted to introduce a CTC. In the final stage (steps 24-27), maxi-preparation of BAC DNA was conducted. 


\section{RESULTS}

\section{$1^{\text {st }}$ gain \& loss screening system}

Two different BAC recombineering systems are widely used including those based on bacterial phage-encoded recombinases; one uses episomal plasmids to supply RecET of the Rac phage (Zhang et al. 1998; Muyrers et al. 2000) and the other utilizes a temperature-sensitive lamda repressor to control the expression of lamda-red recombinase (Yu et al. 2000; Lee et al. 2001). Lamda-red recombinase appears to be at least 50- to 100-fold more efficient than the RecET system (Zhang et al. 1996). Thus, methodology based on the lamda-red recombinase was selected in this study.

SW105 bacteria strain has been genetically modified to have the lamda-red recombinase system. It has a PL operon encoding lamda-red recombinase (exo, bet, and gam) that plays a crucial role in the recombineering process. The PL operon is under strict control of the temperature-sensitive lamda repressor (cI857). At low temperatures in the range of $30-34^{\circ} \mathrm{C}$, cI857 is active and binds to the operator site thereby preventing transcription of the recombinant genes. Thermal upshift to $42^{\circ} \mathrm{C}$ reversibly inhibits the activity of cI857, thereby activating transcription of the recombinant genes.

For the recombineering, a 5' homology region (HR) and 3' HR was introduced into the BAC targeting vector (BTV, Addgene ID: 131589) containing GOI and a kanamycin resistant gene (KanR) (Fig. 1A). To purify BAC targeting cassette (BTC), the BTV with HRs was cut with appropriate XhoI and XmaI (Fig. 1A). As BTC contains KanR with two flanking FRT sites, the recombination of BTC with a $\mathrm{BAC}$ clone after brief heat shock at $42^{\circ} \mathrm{C}$ will result in a positive clone, which has dual antibiotic resistant genes, $\operatorname{KanR}$ (from BTC) and chloramphenicol resistant gene (CamR; from the BAC).

Following the recombineering, a LB plate containing Cam and Kan was used to discriminate the candidate clone(s). The number of candidate colonies appeared after $48 \mathrm{~h}$ incubation at $32^{\circ} \mathrm{C}$ was summarized in Fig. 1B. As BTV in supercoiled form cannot be efficiently cleaved with restriction enzymes, non-cleaved BTVs may be included in the purified BTC. BTV contamination will result in a non-recombinant clone, which has triple antibiotic resistant genes, an ampicillin resistant gene (AmpR; from BTV), KanR (from BTV) and CamR (from the BAC). To identify the clones derives from the desired recombination, the $1^{\text {st }}$ gain $\&$ loss screening system was applied (Fig. 1C). The candidate clones on the plate was inoculated in the $1^{\text {st }}$ gain \& loss screening system and incubated for $24 \mathrm{~h}$ (Fig. 1C). This system will exhibit the three possible cases (Fig. 1C).

1) Case\#1: positive in LB with Cam, positive with Amp, positive with Kan (no recombination)

2) Case\#2: negative in LB with Cam, positive with Amp, positive with Kan (no recombination)

3) Case\#3: positive in LB with Cam, negative with Amp, positive with Kan (recombination) 
Case\#3 only occurs if the recombineering is successful. The average efficiency of obtaining a case\#3 was $31.94 \%$ (Fig. 1D). To confirm the correct recombination, colony PCR was conducted on all clones from case\#3. The forward (Fwd) primer was located in the BAC vector and reverse (Rev) primer in BTC (Fig. 1E). The size of PCR product in 5' recombineered and 3' recombineered region was approximately $280 \mathrm{bp}$ and $500 \mathrm{bp}$, respectively, indicating the successful recombineering (Fig. 1F). Following PCR, DNA sequencing was performed to verify the recombinant region. All positive clones were found to exhibit recombinant sequences indicating $100 \%$ accuracy of $1^{\text {st }}$ gain \& loss screening system (Fig. 1F). Taken together, these results imply that simple inoculation of cells into the screening system visually displayed the positive clones with $100 \%$ accuracy.

\section{$2^{\text {nd }}$ gain $\&$ loss screening system}

During the $1^{\text {st }}$ recombineering step, successful recombination was carried out through the introduction of KanR. However, KanR should be deleted for subsequent experiments. The SW105 strain harbors an endogenous L-arabinose-inducible FLP gene. Since KanR is flanked by two FRT sites, the induced FLP gene in the presence of L-arabinose will delete KanR (Fig. 2A).

Following FLP induction, a LB plate containing Cam was used to discriminate the candidate clone(s). The number of candidate colonies appeared after $48 \mathrm{~h}$ incubation at $32^{\circ} \mathrm{C}$ was summarized in Fig. 2B. The $2^{\text {nd }}$ gain $\&$ loss screening system was used to determine whether the flip-out reaction was successful (Fig. 2C). The positive clones on the plate was inoculated and incubated for $24 \mathrm{~h}$ (Fig. 2C). This system will exhibit the two possible cases (Fig. 2C).

1) Case\#1: positive in LB with Cam, positive with Kan (no flip-out)

2) Case\#2: positive in LB with Cam, negative with Kan (flip-out)

Case\#2 only occurs if the flip-out is successful. The average efficiency of obtaining a case\#2 was $100 \%$ (Fig. 2D). To confirm the correct flip-out, colony PCR was conducted on all the clone from case\#2. Two primers were located outside of the two FRT sites (Fig. 2E). The size of PCR product in flip-out region was approximately $100 \mathrm{bp}$, indicating the successful flip-out (Fig. 2F). Following PCR, DNA sequencing was performed to verify the flip-out region. All positive clones were found to exhibit recombinant sequences indicating $100 \%$ accuracy of $2^{\text {nd }}$ gain $\&$ loss screening system (Fig. 2F). Taken together, these results confirmed the accuracy of the $2^{\text {nd }}$ gain $\&$ loss screening system to $100 \%$.

\section{$3^{\text {rd }}$ gain \& loss screening system}

To facilitate integration of the BAC construct into the genome, the Tol 2 transposon system was used (Suster et al. 2011). The Tol2 transposon system yields the highest rate of genomic integration in the germ lineage resulting in the increased production of desired proteins (Suster et 
al. 2011; Balasubramanian et al. 2016). As CamR is located on a backbone vector of BAC clones, CamR was targeted to introduce the Tol2 transposon system. For the recombineering, a 5' \& 3' CamR HR was introduced into the Cam targeting vector (CTV, Addgene ID: 131590) containing inverted left \& right Tol2 transposons, AmpR for gain \& loss screening, and a neomycin resistance (NeoR) gene for a mammalian selection marker (Fig. 3A). To purify chloramphenicol targeting cassette (CTC), CTV was cut with BamHI and XhoI (Fig. 3A).

As the recombination of CTC with a flip-out positive clone will lose CamR but acquire AmpR (from CTC), a LB plate containing Amp was used to discriminate the candidate clone(s). The number of candidate colonies appeared after $48 \mathrm{~h}$ incubation at $32^{\circ} \mathrm{C}$ was summarized in Fig. 3B. As CTV in supercoiled form cannot be efficiently cleaved with restriction enzymes, noncleaved CTVs may be included in the purified CTC. CTV contamination will result in a nonrecombinant clone, which has double antibiotic resistant genes, AmpR (from CTV) and CamR (from the BAC). To differentiate whether the clone derives from the desired recombination, the $3^{\text {rd }}$ gain $\&$ loss selection system was used. The candidate clones on the plate was inoculated in the $3^{\text {rd }}$ gain \& loss selection system and incubated for $24 \mathrm{~h}$ (Fig. 3C). This system will exhibit the three possible cases (Fig. 3C).

1) Case\#1: positive in LB with Cam, negative with Amp (no recombination)

2) Case\#2: positive in LB with Cam, positive with Amp (no recombination)

3) Case\#3: negative in LB with Cam, positive with Amp (recombination)

Case\#3 only occurs if the recombineering is successful. The average efficiency of obtaining a case\#3 was $75.69 \%$ (Fig. 3D). To confirm the correct recombination, colony PCR was conducted on all the clone from case\#3. The Fwd primer was located in the BAC vector and the Rev primer in the CTC (Fig. 3E). If a recombineering occurred, the PCR product of 5' recombineered and 3' recombineered region should be approximately $400 \mathrm{bp}$ and $390 \mathrm{bp}$, respectively (Fig. 3F). Following PCR, DNA sequencing was performed to verify the recombinant region. All positive clones were found to exhibit recombinant sequences indicating $100 \%$ accuracy of $3^{\text {rd }}$ gain $\&$ loss screening system (Fig. 3F). Taken together, these results also confirmed the accuracy of the third screening system to $100 \%$.

\section{More strategies to increase recombination efficiency}

The efficiency of the $2^{\text {nd }} \mathrm{BAC}$ recombineering (75.69\%) was 2 times higher than that of the $1^{\text {st }}$ BAC recombineering (31.94\%). This discrepancy is presumed to be due to the difference in HR length, the decisive for the recombination efficiency (Sharan et al. 2009; Kung et al. 2013). However, the length of 5' HR (473 bp) and 3' HR (486 bp) in BTV was longer than 5' HR (200 bp) and 3' HR (200 bp) in CTV, so other factors may be involved in this discrepancy. Incomplete enzymatic digestion of the targeting vector increases the number of false positive clones, thereby 
reducing recombination efficiency (Jacobus and Gross 2015). Strategies to induce complete enzymatic digestion are required, but incomplete digestion may occur due to several other factors including DNA methylation (23). Thus, we hypothesized that strategy to distinguish between linear DNA and uncut circular DNA would increase the recombination efficiency. As a low percentage of agarose gel can distinguish fast-moving linear DNA fragments from slow-moving circular DNA (Lee et al. 2012), we used 0.2\% agarose gel and differentiated the linearized BTC (4.7 kb; red rectangle) from uncut BTV (7.6 kb; yellow rectangle) (Fig. 4A). Then, the $1^{\text {st }}$ BAC recombineering was performed again. The efficiency of the $1^{\text {st }}$ BAC recombineering increased from $31.94 \%$ to $59.38 \%$, indicating that a strategy to purify the targeting cassette on a low percentage of agarose gel can be another decisive factor for the efficient recombineering (Fig. 4A).

Targeting vector is high copy number plasmid, while BAC is low copy number plasmid. A high copy number plasmid replicates autonomously from the bacterial chromosome and is generally present in more than one copy per cell, providing higher antibiotic resistance (Jahn et al. 2016). CTV has AmpR for selection, so bacteria with uncut CTV with non-recombinant BACs can grow better than bacteria with recombinant BACs. Thus, we hypothesized that the selection of small colony will increase the recombination efficiency. Following the $2^{\text {nd }}$ recombineering, the candidate clones were distinguished using LB plates containing Amp. After $48 \mathrm{~h}$ incubation at $32^{\circ} \mathrm{C}$, colonies appeared as shown graphically in Fig. 4B. To test our hypothesis, large colonies (larger than $1 \mathrm{~mm}$ ) were selected from one group and small colonies (smaller than $1 \mathrm{~mm}$ ) from the other group. The recombination efficiency obtained when selecting small colonies was increased by about 1.6-fold compared to when selecting large colonies (47.92\% vs. $29.17 \%$, Fig. 4B). 


\section{DISSCUSSION}

The rapid and efficient screening system is crucial for the BAC recombineering procedure. The importance of the screening system was realized by a strategy to reduce the number of false positive clones by performing long digestion of the targeting vector (Carreira-Rosario et al. 2013). However, due to many false positive clones, it still takes too much time to find a real recombinant clone (Carreira-Rosario et al. 2013). Another strategy have been attempted to avoid false positive clones from non-cleaved targeting vectors using PCR amplification of the targeting vector with PCR primers containing HR (Sharan et al. 2009). This strategy was also hampered by a false positive clones derived from PCR templates or unavoidable PCR errors during PCR amplification of the targeting vector (Sharan et al. 2009). In the current study, we uncovered a novel strategy in which simple inoculation of cells visually revealed the positive clones within $24 \mathrm{~h}$. This strategy is based on whether cells can survive in the medium with specific antibiotics. Combination of survival or non-survival in a medium containing antibiotics was used a tool to determine whether a clone has a real recombined BAC or comes from a false positive background. The accuracy of this screening was confirmed by DNA sequencing results showing that all positive clones exhibited recombinant sequences. To our knowledge, our study provides the first demonstration that new gain \& loss screening scheme enables $100 \%$ accuracy opening a new horizon in the field of BAC recombineering.

BAC recombination consists of time-consuming steps including $1^{\text {st }}$ recombineering, flip out and $2^{\text {nd }}$ recombineering. This time-consuming procedure has been a major obstacle for researchers starting $\mathrm{BAC}$ recombineering. Procedures to reduce $\mathrm{BAC}$ recombination duration are the most demanding criteria for researchers to conduct BAC recombination. The $100 \%$ accurate gain \& loss screening system facilitated recombineering process by making each recombination process successful at once. Furthermore, the increased recombination efficiency by using long HR promoted recombination progress by allowing identification of the recombinant clones out of only 48 colonies per step. The efficiency of the $1^{\text {st }}$ and $2^{\text {nd }}$ BAC recombineering was $31.94 \%$ and $75.69 \%$, respectively, whereas that of traditional BAC recombineering with short HRs was less than $10 \%$ (Liu et al. 2003). Thus, our new strategy allowed us to complete the entire BAC recombineering procedure within just 13 days (Fig. 5). Taken together, considering short duration, we expect that this protocol will open a new path for laboratories with less experience in the field of BAC recombineering.

Recombineering is a genetic and molecular biology technique based on homologous recombination systems, which mediate efficient recombination of linear DNA molecules flanked by long HR (Thomason et al. 2014). The significance of long HR is highlighted by the finding that the targeting cassette with long HR (200-500 bp) is more efficient for recombineering than the targeting cassette with short HR (approximately 50 bp) (Degryse 1996; Sharan et al. 2009; 
Dickinson et al. 2015). Targeting vectors with long HR were linearized by restriction digestion and purified in preparation for subsequent use in BAC recombineering steps. Long-term DNA digestion is crucial for complete digestion, but incomplete digestion can occur if enzyme activity is blocked by DNA methylation (Snounou and Malcolm 1984). As non-cleaved targeting vectors are inevitable, a new strategy is needed to avoid false positive clones. Here, we found that a novel tool using a low percentage of agarose gel increased the likelihood of obtaining recombinant clones by effectively avoiding uncut targeting vectors. The significance of a novel approach was supported by the results showing that the $1^{\text {st }}$ BAC recombination efficiency increased from $31.94 \%$ to $59.38 \%$. Taken together, our results imply that this new approach can be considered an alternative to solving problems that may arise when using long HR in targeting vectors.

BAC is based on an F-factor plasmid that maintains a small number of copies in bacterial cells, while the targeting vector is a high copy number plasmid (Asami et al. 2011). A low copy number plasmid has only one or a few copies in each bacterium, so antibiotic resistance is low compared to high copy number plasmids (Jahn et al. 2016). Thus, bacteria with low copy number plasmid grow slower than bacteria with high copy number plasmid in the presence of antibiotics (Trivedi et al. 2014). In this study, we proposed a novel strategy that use the growth differences between bacteria with recombinant BAC and bacteria without recombinant BAC. Bacteria with recombinant $\mathrm{BAC}$ are presumed to grow slower than bacteria with both unrecombined BAC and targeting vectors. This strategy was validated by the results showing that the recombination efficiency obtained when selecting small colonies was 1.6 times higher than when selecting large colonies. Based on these findings, we conclude that a strategy using growth differences in the presence of antibiotics will be another alternative that promotes fast and efficient BAC recombination.

In summary, we have developed a new strategy that makes it easy to visually confirm the success of BAC recombineering and reduce the overall processing time to less than two weeks (13 days) (Fig. 5). This new screening system will provide significant advances in current methodologies for BAC recombineering and might be of broad interest to many researchers in different fields including biopharmaceutical protein expression and other large-vector applications for various transgenic animals.

\section{Author Contributions}

MUK and JTP conceived of and designed the experiments. MUK performed the experiments. MUK, SO, and JTP wrote and edited the paper.

\section{Acknowledgements}


This research was supported by a Basic Science Research Program through the National Research Foundation of Korea (NRF) funded by the Ministry of Science, ICT, and Future Planning (NRF2018R1D1A1B07040293). This research was also supported by Research Assistance Program (2019) in the Incheon National University.

\section{Financial disclosure}

The authors declare no conflicts of interest.

\section{Information pertaining to writing assistance}

The authors declare no writing assistance

\section{Ethical disclosure}

The authors state that they have followed the principles outlined in the Declaration of Helsinki for all human or animal experimental investigations. In addition, for investigations involving human subjects, informed consent has been obtained from the participants involved.

\section{Data sharing statement}

The authors declare that they shall make data available to the scientific community without any restrictions. 


\section{References}

Asami J, Inoue YU, Terakawa YW, Egusa SF, Inoue T. 2011. Bacterial artificial chromos omes as analytical basis for gene transcriptional machineries. Transgenic Res 20: 9 13-924.

Balasubramanian S, Rajendra Y, Baldi L, Hacker DL, Wurm FM. 2016. Comparison of th ree transposons for the generation of highly productive recombinant $\mathrm{CHO}$ cell poo 1s and cell lines. Biotechnol Bioeng 113: 1234-1243.

Carreira-Rosario A, Scoggin S, Shalaby NA, Williams ND, Hiesinger PR, Buszczak M. 2 013. Recombineering homologous recombination constructs in Drosophila. J Vis Ex $p$ doi:10.3791/50346: e50346-e50346.

Degryse E. 1996. In vivo intermolecular recombination in Escherichia coli: application to plasmid constructions. Gene 170: 45-50.

Dickinson DJ, Pani AM, Heppert JK, Higgins CD, Goldstein B. 2015. Streamlined Geno me Engineering with a Self-Excising Drug Selection Cassette. Genetics 200: 10351049.

Giraldo P, Montoliu L. 2001. Size Matters: Use of YACs, BACs and PACs in Transgenic Animals. Transgenic Res 10: 83-103.

Jacobus AP, Gross J. 2015. Optimal cloning of PCR fragments by homologous recombinat ion in Escherichia coli. PLoS One 10: e0119221-e0119221.

Jahn M, Vorpahl C, Hübschmann T, Harms H, Müller S. 2016. Copy number variability of expression plasmids determined by cell sorting and Droplet Digital PCR. Micro bial Cell Factories 15: 211.

Kung SH, Retchless AC, Kwan JY, Almeida RPP. 2013. Effects of DNA size on transfor mation and recombination efficiencies in Xylella fastidiosa. Appl Environ Microbiol 79: $1712-1717$.

Lee EC, Yu D, Martinez de Velasco J, Tessarollo L, Swing DA, Court DL, Jenkins NA, Copeland NG. 2001. A highly efficient Escherichia coli-based chromosome enginee ring system adapted for recombinogenic targeting and subcloning of BAC DNA.

Genomics 73: 56-65.

Lee PY, Costumbrado J, Hsu C-Y, Kim YH. 2012. Agarose gel electrophoresis for the se paration of DNA fragments. J Vis Exp doi:10.3791/3923: 3923.

Liu P, Jenkins NA, Copeland NG. 2003. A highly efficient recombineering-based method f or generating conditional knockout mutations. Genome Res 13: 476-484.

Muyrers JP, Zhang Y, Benes V, Testa G, Ansorge W, Stewart AF. 2000. Point mutation o f bacterial artificial chromosomes by ET recombination. EMBO Rep 1: 239-243.

Rita Costa A, Elisa Rodrigues M, Henriques M, Azeredo J, Oliveira R. 2010. Guidelines 
to cell engineering for monoclonal antibody production. Eur J Pharm Biopharm 7 4: $127-138$.

Sharan SK, Thomason LC, Kuznetsov SG, Court DL. 2009. Recombineering: a homologou s recombination-based method of genetic engineering. Nat Protoc 4: 206-223.

Snounou G, Malcolm AD. 1984. Supercoiling and the mechanism of restriction endonuclea ses. Eur J Biochem 138: 275-280.

Suster ML, Abe G, Schouw A, Kawakami K. 2011. Transposon-mediated BAC transgenesi S in zebrafish. Nat Protocols 6: 1998-2021.

Thomason LC, Sawitzke JA, Li X, Costantino N, Court DL. 2014. Recombineering: genet ic engineering in bacteria using homologous recombination. Current protocols in $\mathrm{m}$ olecular biology 106: 1.16.11-39.

Trivedi RN, Akhtar P, Meade J, Bartlow P, Ataai MM, Khan SA, Domach MM. 2014. H igh-Level Production of Plasmid DNA by Escherichia coli DH5 $\alpha$ sacB by Introd ucing inc Mutations. Appl Environ Microbiol 80: 7154-7160.

Wurm FM. 2004. Production of recombinant protein therapeutics in cultivated mammalian cells. Nat Biotechnol 22: 1393-1398.

Yu D, Ellis HM, Lee EC, Jenkins NA, Copeland NG, Court DL. 2000. An efficient reco mbination system for chromosome engineering in Escherichia coli. Proc Natl Acad Sci U S A 97: 5978-5983.

Zhang Y, Buchholz F, Muyrers JP, Stewart AF. 1998. A new logic for DNA engineering using recombination in Escherichia coli. Nat Genet 20: 123-128.

Zhang Y, Riesterer C, Ayrall A-M, Sablitzky F, Littlewood TD, Reth M. 1996. Inducible Site-Directed Recombination in Mouse Embryonic Stem Cells. Nucleic Acids Resea rch 24: 543-548. 


\section{FIGURE LEGENDS}

Fig. 1. Detailed procedure and results for the $1^{\text {st }}$ recombineering. (A) Overview of the BAC targeting vector (BTV, Addgene ID: 131589) and BAC targeting cassette (BTC). (B) Summary of colony numbers in LB plates containing Cam and different concentrations of Kan following the $1^{\text {st }}$ BAC recombineering. (C) Illustration of the $1^{\text {st }}$ gain $\&$ loss selection system for identifying recombinant clones. Red asterisk (*) indicates the recombineering-positive clone. (D) Efficiency of the $1^{\text {st }}$ recombineering after performing the $1^{\text {st }}$ gain $\&$ loss selection system. Means \pm S.D., $N=$ 3. (E) $1^{\text {st }}$ recombineering scheme and position of colony PCR primers for recombination confirmation. (F) Picture of agarose gel electrophoresis showing colony PCR results. PCR product was only amplified in the recombineering-positive clone. Chromatogram results showing that the sequence of the amplified PCR product was conserved compared to the reference sequence at the genome-BTC boundary.

Fig. 2. Detailed procedure and results for the flip-out reaction.

(A) Overview of the flip-out reaction. In the presence of L-arabinose, the endogenous Larabinose-inducible FLP gene in the SW105 strain will delete KanR flanked by two FRT sites. (B) Summary of colony numbers in LB plates containing Cam after the flip-out reaction. (C) Inoculation of positive clones into the $2^{\text {nd }}$ gain $\&$ loss selection system. (C) Illustration of the $2^{\text {nd }}$ gain \& loss selection system for identifying recombinant clones. Red asterisk (*) indicates a flipout positive clone. (D) Efficiency of flip-out reaction after performing the $2^{\text {nd }}$ gain $\&$ loss selection system. Means \pm S.D., $N=3$. (E) Flip-out scheme and location of colony PCR primers for confirming flip-out reaction. (F) Picture of agarose gel electrophoresis showing colony PCR results. PCR product was only amplified in the flip-out positive clone. Chromatogram results showing that the sequence of the amplified PCR product was conserved compared to the reference sequence at the border where flip-out was completed.

Fig. 3. Detailed procedure and results for the $2^{\text {nd }}$ recombineering. (A) Overview of Cam targeting vector (CTV, Addgene ID: 131590) and Cam targeting cassette (CTC). (B) Summary of colony numbers in LB plates containing different concentrations of Amp after the $2^{\text {nd }}$ BAC recombineering. (C) Illustration of the $3^{\text {rd }}$ gain $\&$ loss selection system for identifying recombinant clones. Red asterisk (*) indicates the recombineering-positive clone. (D) Efficiency of the $2^{\text {nd }}$ recombineering after performing the $3^{\text {rd }}$ gain $\&$ loss selection system. Means \pm S.D., $N$ $=3$. $(\mathrm{E}) 2^{\text {nd }}$ recombineering scheme and position of colony PCR primers for recombination confirmation. (F) Picture of agarose gel electrophoresis showing colony PCR results. PCR product was only amplified in the recombineering-positive clone. Chromatogram results showing that the sequence of the amplified PCR product was conserved compared to the reference 
sequence at the genome-CTC boundary.

Fig. 4. More strategies to increase recombination efficiency. (A) Picture of agarose gel electrophoresis showing the uncut BTV (7.6 kb; yellow rectangle), the linearized BTC (4.7 kb; red rectangle) and the vector backbone of BTV ( $2.9 \mathrm{~kb}$; blue rectangle) after enzyme digestion of BTV with XhoI and XmaI. Efficiency of the $1^{\text {st }}$ recombineering after performing the $1^{\text {st }}$ gain \& loss selection system. Means \pm S.D., $N=2$. (B) Illustration of colonies in LB plate containing Amp after the $2^{\text {nd }} \mathrm{BAC}$ recombineering. After $48 \mathrm{~h}$ incubation at $32^{\circ} \mathrm{C}$, colonies appeared. Large colonies (larger than $1 \mathrm{~mm}$ ) were selected from one group and small colonies (smaller than 1 $\mathrm{mm}$ ) from the other group. Efficiency of the $2^{\text {nd }}$ recombineering after performing the $3^{\text {rd }}$ gain $\&$ loss selection system in a larger or smaller colony-selected group. Means \pm S.D., $N=3$.

Fig. 5. Summary of the experimental procedure and timing for each step.

Supplementary Fig. 1. Overview of the experiment procedure and estimated timing of each step.

Supplementary Fig. 2. Identification and procurement of the desired BAC.

Supplementary Fig. 3. Identification and procurement of the desired BAC.

Supplementary Fig. 4. Identification and procurement of the desired BAC.

Supplementary Fig. 5. Identification and procurement of the desired BAC.

Supplementary Fig. 6. Identification and procurement of the desired BAC. 
Fig. 1

A

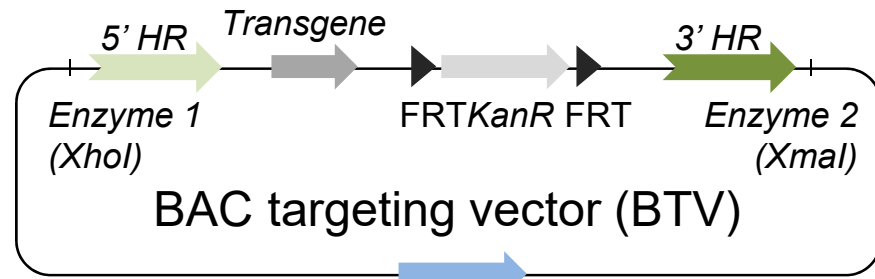

AmpR

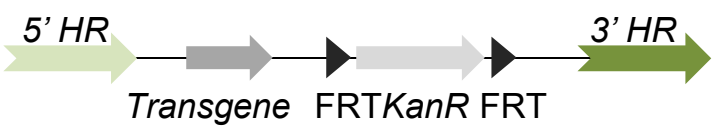

BAC targeting cassette (BTC)

C

$1^{\text {st }}$ gain \& loss selection

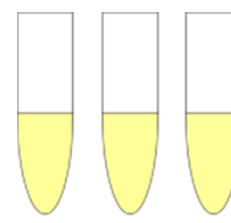

Cam Amp Kan

No

recombination

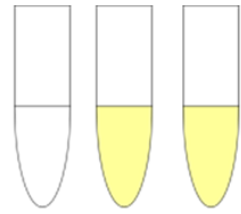

Cam Amp Kan

No recombination

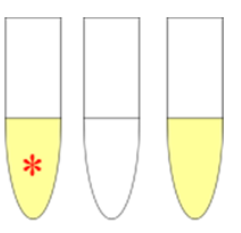

Cam Amp Kan

Recombination
B

\begin{tabular}{cccccc}
\hline \multirow{2}{*}{$\begin{array}{c}\text { Concentration Plate } \\
\text { of antibiotics }\end{array}$} & No & \multicolumn{5}{c}{ Experiment } \\
\cline { 3 - 5 } & & $\# 1$ & $\# 2$ & $\# 3$ & group \\
\hline Cam $12.5 \mu \mathrm{g} / \mathrm{ml}$ & 1 & 1510 & 1672 & 1672 & \\
& 2 & 2455 & 1537 & 1457 & 0 \\
Kan $20 \mu \mathrm{g} / \mathrm{ml}$ & 3 & 1403 & 1214 & 1591 & \\
\hline Cam $12.5 \mu \mathrm{g} / \mathrm{ml}$ & 1 & 1915 & 1295 & 1618 & \\
Kan $25 \mu \mathrm{g} / \mathrm{ml}$ & 2 & 1672 & 998 & 1187 & 0 \\
\hline Cam $12.5 \mu \mathrm{g} / \mathrm{ml}$ & 1 & 1430 & 1349 & 1457 & \\
\hline & 2 & 1672 & 1403 & 1295 & 0 \\
Kan $30 \mu \mathrm{g} / \mathrm{ml}$ & 3 & 863 & 1295 & 998 & \\
\hline
\end{tabular}

$E$

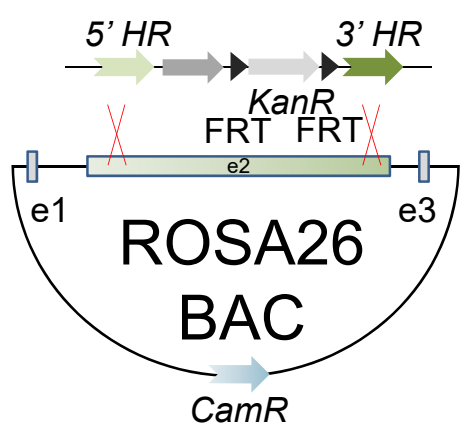

Recombineering

Fwd(i) $\operatorname{Rev}(i) \quad F w d(i i) \operatorname{Rev}(i i)$

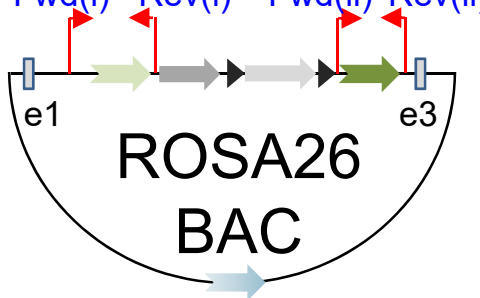

CamR

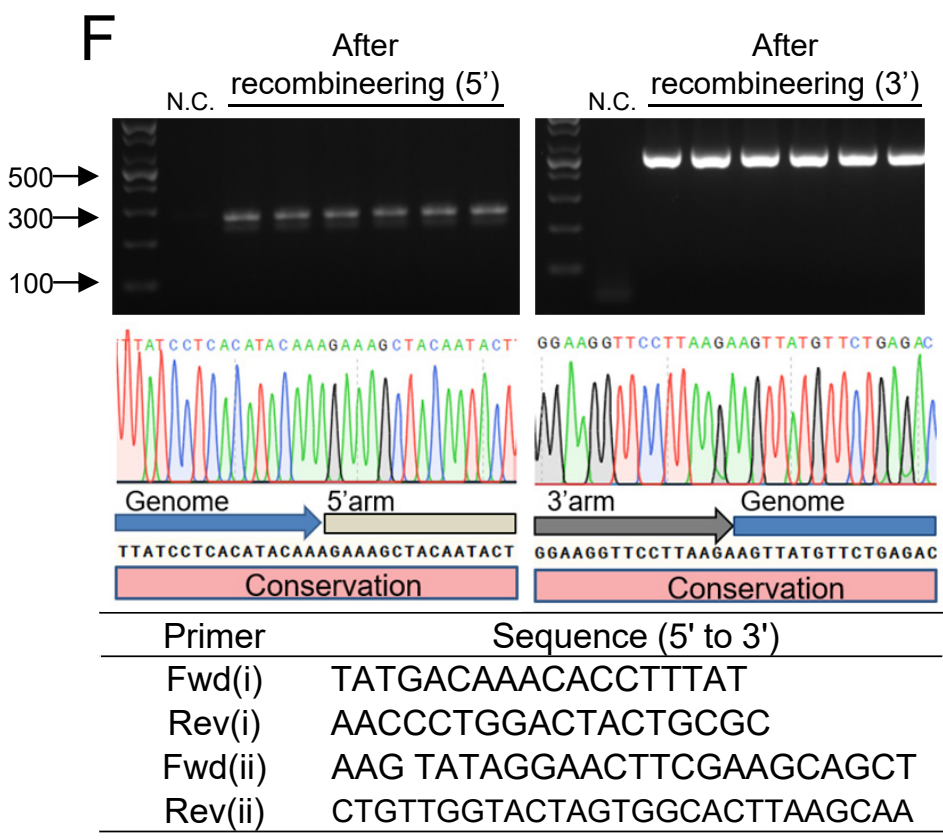


bioRxiv preprint doi: https://doi.org/10.1101/2020.06.22.166017; this version posted June 23, 2020. The copyright holder for this preprint (which was not certified by peer review) is the author/funder, who has granted bioRxiv a license to display the preprint in perpetuity. It is made available under aCC-BY-NC-ND 4.0 International license.

Fig. 2

A

B

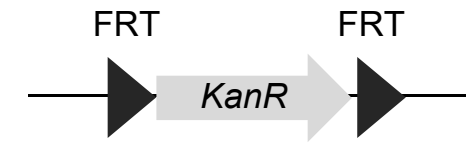

Flippase

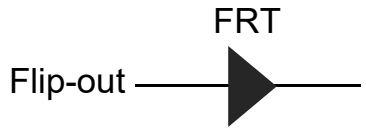

C

$2^{\text {nd }}$ gain \& loss selection

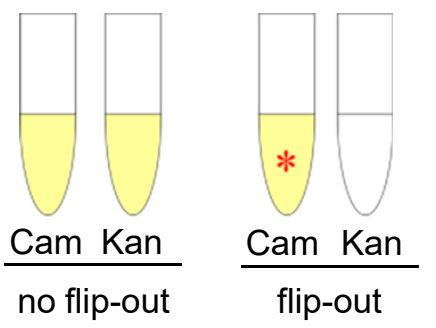

$E$
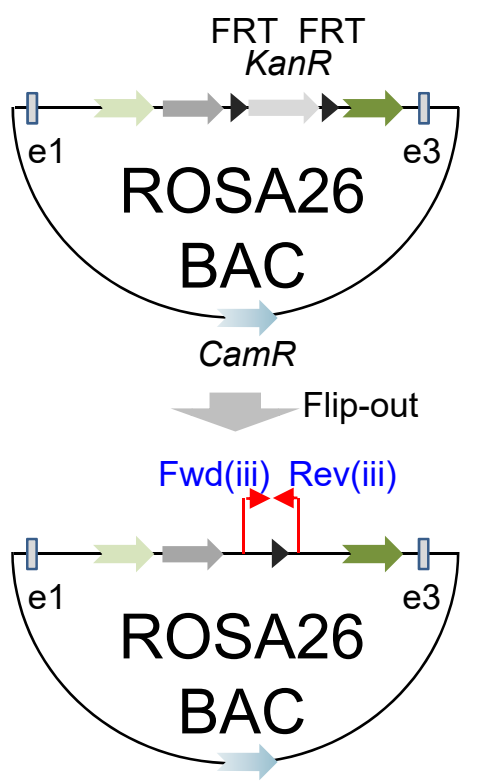

CamR

\begin{tabular}{ccccc}
\hline \multirow{2}{*}{$\begin{array}{c}\text { Concentration of a } \\
\text { ntibiotics }\end{array}$} & Plate & \multicolumn{3}{c}{ Colony Number } \\
\cline { 3 - 5 } & No & \multicolumn{3}{c}{ Experiment Group } \\
\cline { 3 - 5 } & 1 & 970 & 749 & 1805 \\
\hline \multirow{3}{*}{ Cam $12.5 \mu \mathrm{g} / \mathrm{mL}$} & 2 & 806 & 854 & 2150 \\
& 3 & 595 & 1114 & 2035 \\
\hline
\end{tabular}

D

\begin{tabular}{cccc}
\hline & \multicolumn{3}{c}{ Colony Number } \\
\cline { 2 - 4 } & Experiment Group \\
\hline $\begin{array}{c}\text { Number of inoculating c } \\
\text { olony }\end{array}$ & 48 & 48 & 48 \\
\hline $\begin{array}{c}\text { Number of positive colo } \\
\text { ny }\end{array}$ & 48 & 48 & 48 \\
\hline $\begin{array}{c}\text { Flip-out efficiency (\%) } \\
\begin{array}{c}\text { Means } \pm \text { S.D of Flip-out } \\
\text { efficiency (\%) }\end{array}\end{array}$ & 100 & 100 & 100 \\
\hline
\end{tabular}

$\mathrm{F}$

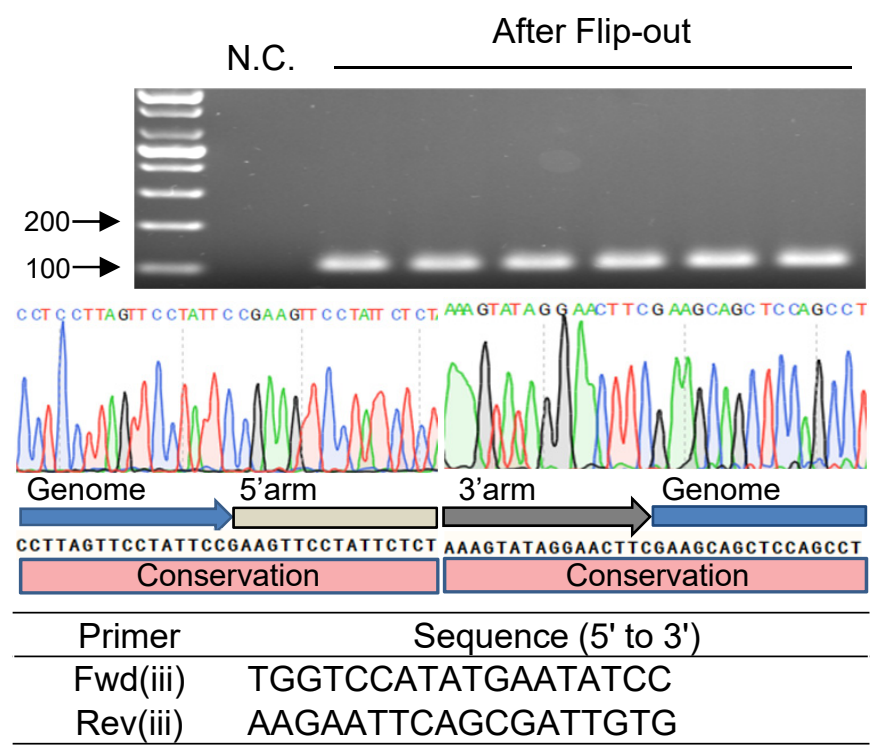


Fig. 3

A

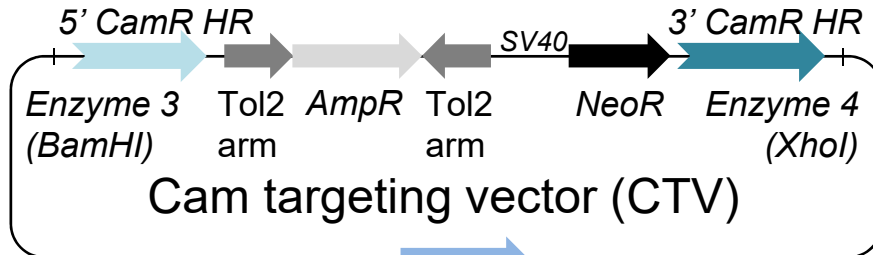

$A m p R$

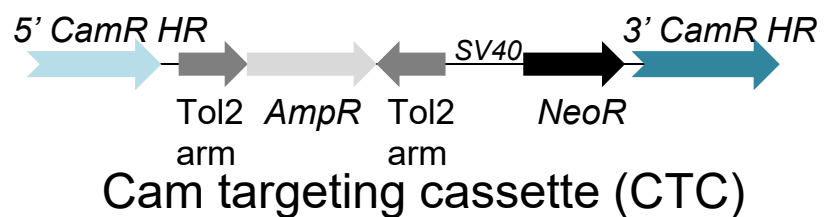

C

\section{$3^{\text {rd }}$ gain \& loss selection}

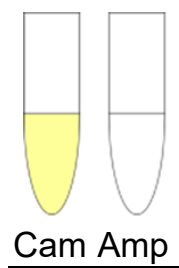

No recombination

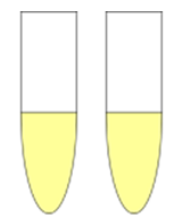

Cam Amp

No recombination

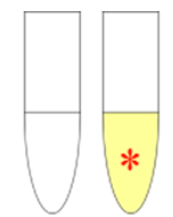

Cam Amp

Recombination

B

\begin{tabular}{lccccc}
\hline \multirow{2}{*}{$\begin{array}{c}\text { Concentration } \\
\text { of antibiotics }\end{array}$} & Plate & \multicolumn{5}{c}{ Colony Number } \\
\cline { 3 - 6 } & No & Experiment Group & DW \\
\cline { 3 - 5 } & 1 & 324 & 432 & 243 & \\
\hline \multirow{3}{*}{ Amp $20 \mu \mathrm{g} / \mathrm{ml}$} & 2 & 351 & 378 & 324 & 0 \\
& 3 & 486 & 297 & 378 & \\
\hline \multirow{3}{*}{ Amp $30 \mu \mathrm{g} / \mathrm{ml}$} & 1 & 162 & 405 & 351 & \\
& 2 & 162 & 108 & 189 & 0 \\
& 3 & 324 & 135 & 378 & \\
\hline \multirow{3}{*}{ Amp $40 \mu \mathrm{g} / \mathrm{ml}$} & 1 & 243 & 81 & 189 & \\
& 2 & 243 & 108 & 81 & 0 \\
& 3 & 135 & 135 & 243 & \\
\hline
\end{tabular}

\begin{tabular}{cccc}
\hline & \multicolumn{3}{c}{ Colony Number } \\
\cline { 2 - 4 } & \multicolumn{3}{c}{ Experiment Group } \\
\cline { 2 - 4 } $\begin{array}{c}\text { Number of inoculating c } \\
\text { olony }\end{array}$ & 48 & 48 & 48 \\
\hline $\begin{array}{c}\text { Number of positive colo } \\
\text { ny }\end{array}$ & 37 & 36 & 36 \\
\hline $\begin{array}{c}\text { Recombineering efficien } \\
\text { cy (\%) }\end{array}$ & 77.08 & 75.00 & 75.00 \\
\hline $\begin{array}{c}\text { Means } \pm \text { S.D of recomb } \\
\text { ineering efficiency (\%) }\end{array}$ & $75.69 \pm 1.20$ \\
\hline
\end{tabular}

E

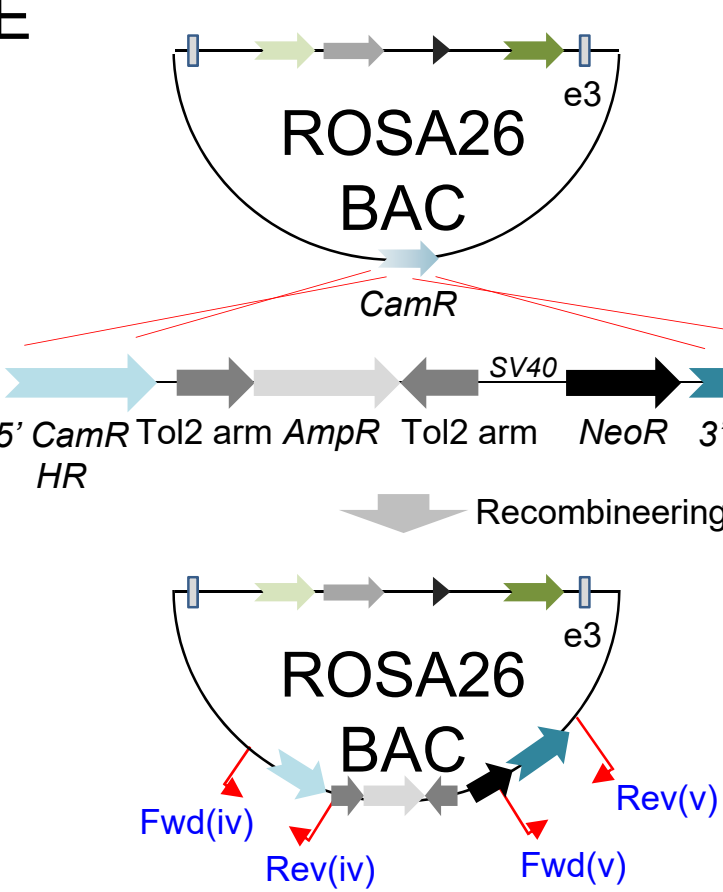




\section{Fig. 4}

A

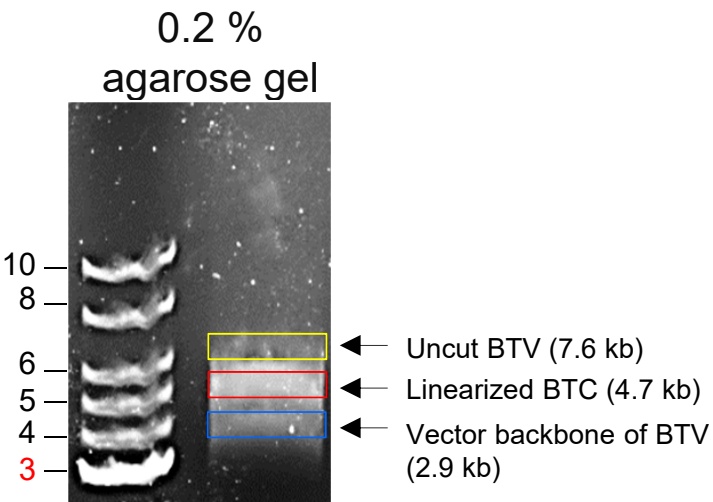

\begin{tabular}{|c|c|c|}
\hline & \multicolumn{2}{|c|}{ Colony Number } \\
\hline & \multicolumn{2}{|c|}{ Experiment Group } \\
\hline & $\# 1$ & \#2 \\
\hline $\begin{array}{c}\text { Number of inoculating colo } \\
\text { ny }\end{array}$ & 48 & 48 \\
\hline Number of positive colony & 31 & 26 \\
\hline $\begin{array}{c}\text { Recombineering efficiency } \\
(\%)\end{array}$ & 64.58 & 54.17 \\
\hline $\begin{array}{c}\text { Means } \pm \text { S.D of recombine } \\
\text { ering efficiency }(\%)\end{array}$ & 59.3 & 5.21 \\
\hline
\end{tabular}

$\mathrm{B}$

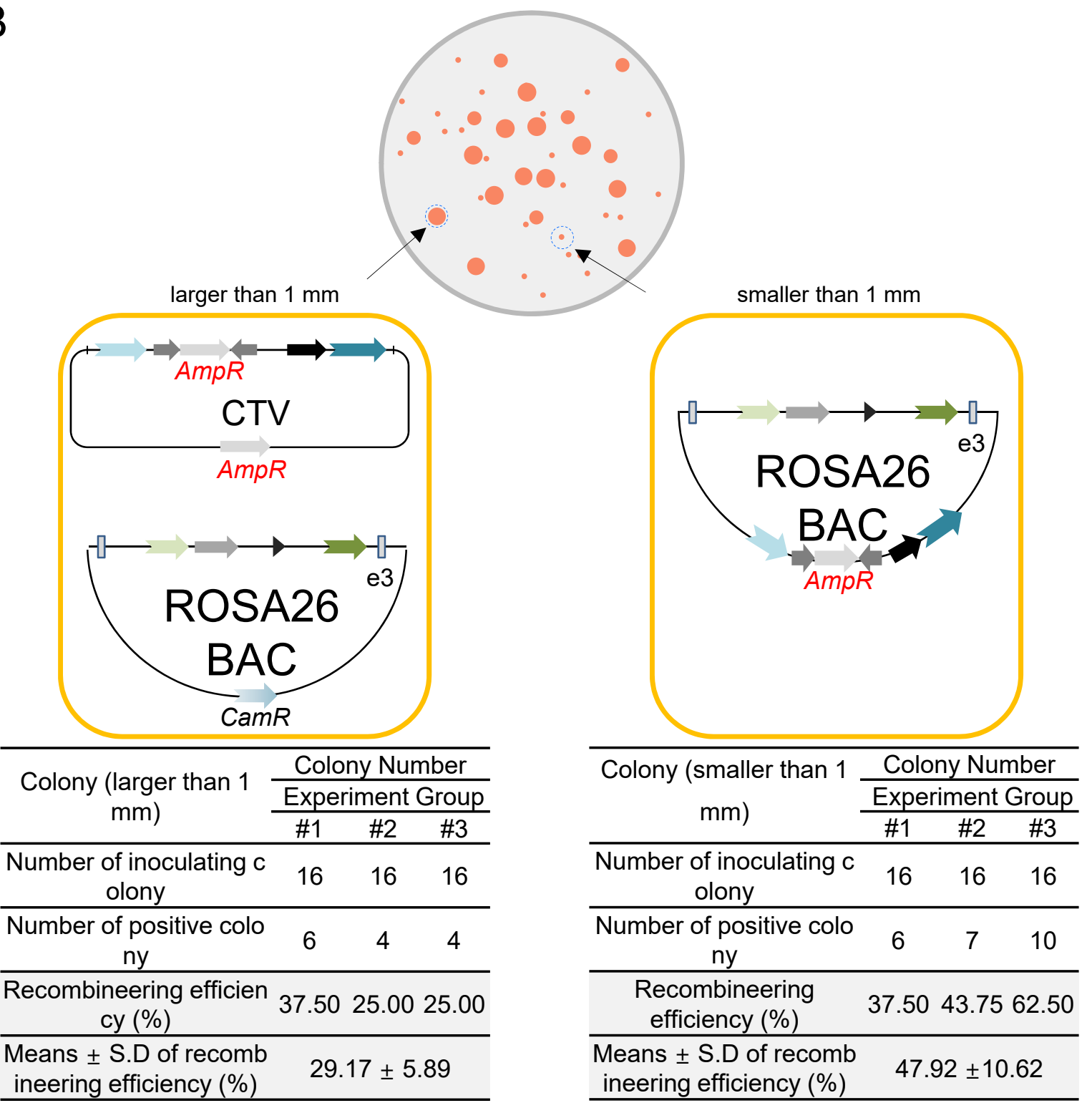


bioRxiv preprint doi: https://doi.org/10.1101/2020.06.22.166017; this version posted June 23, 2020. The copyright holder for this preprint (which was not certified by peer review) is the author/funder, who has granted bioRxiv a license to display the preprint in perpetuity. It is made available under aCC-BY-NC-ND 4.0 International license.

Fig. 5
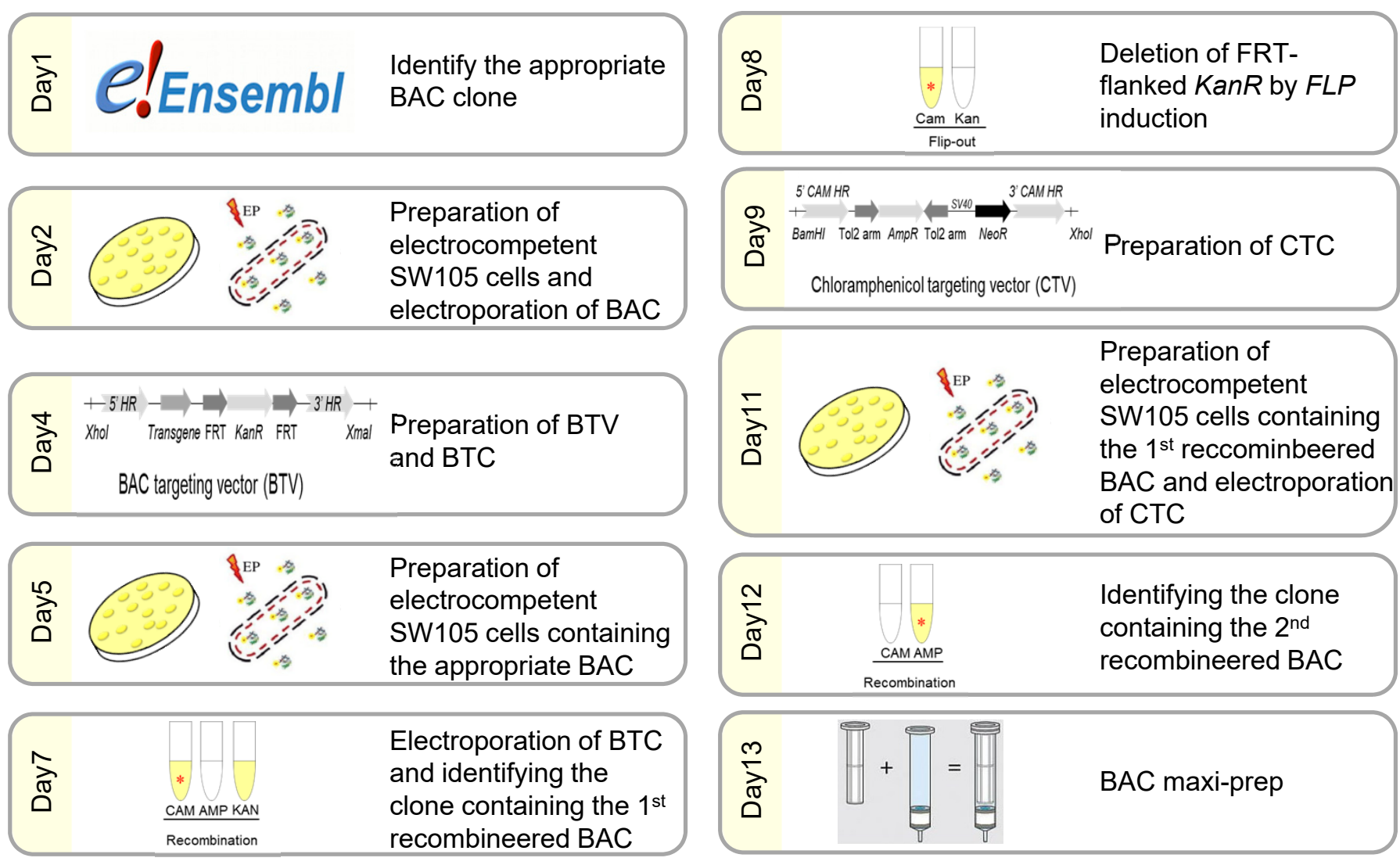


\section{Supplementary Fig. 1}

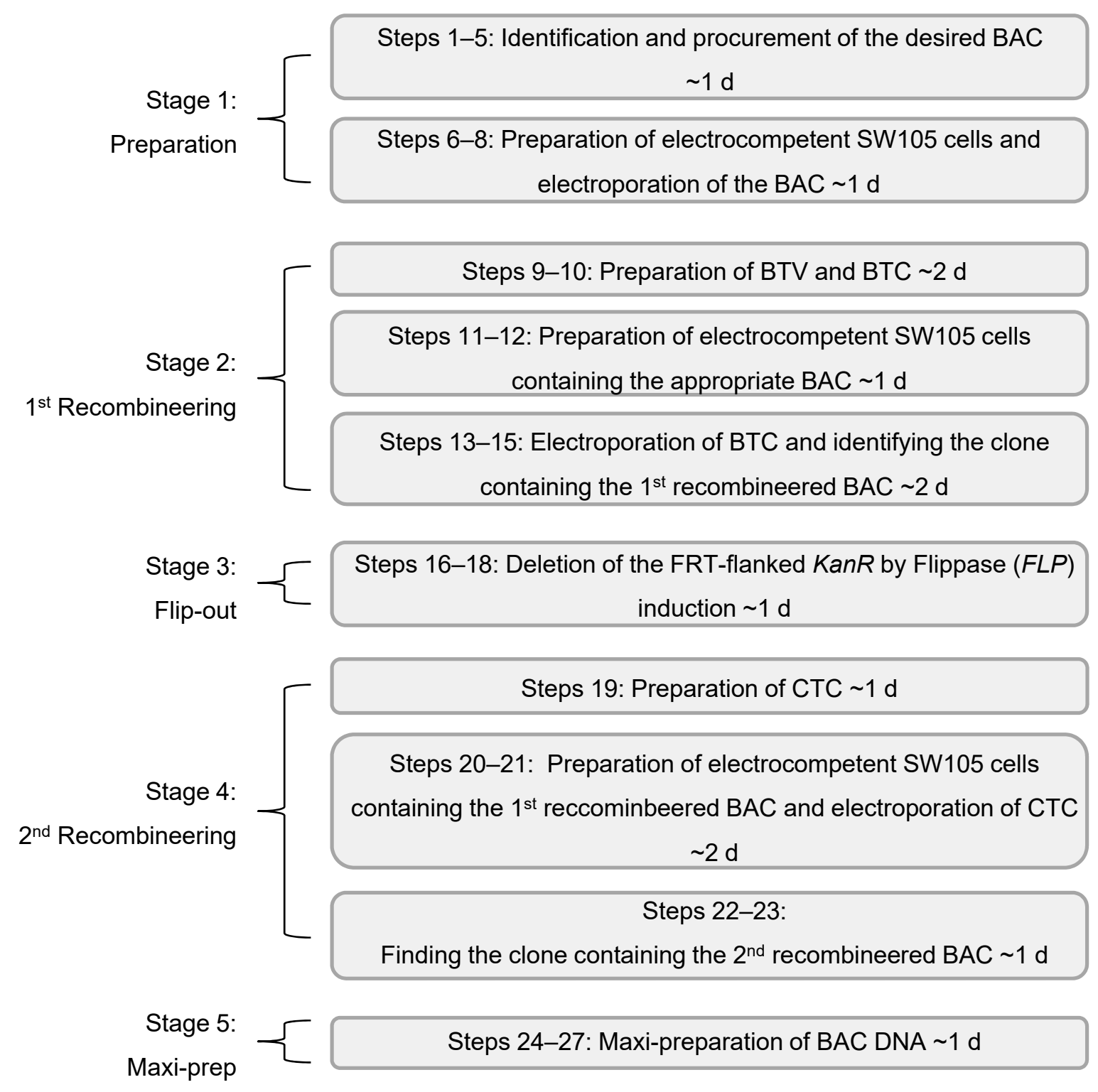


bioRxiv preprint doi: https://doi.org/10.1101/2020.06.22.166017; this version posted June 23, 2020. The copyright holder for this preprint (which was not certified by peer review) is the author/funder, who has granted bioRxiv a license to display the preprint in perpetuity. It is made available under aCC-BY-NC-ND 4.0 International license.

\section{Supplementary Fig. 2}

A

\section{Ensemb| вLAST/BLAT | VEP | Tools | Bionat | Dowmloads | Hep \& Dous | Blog}

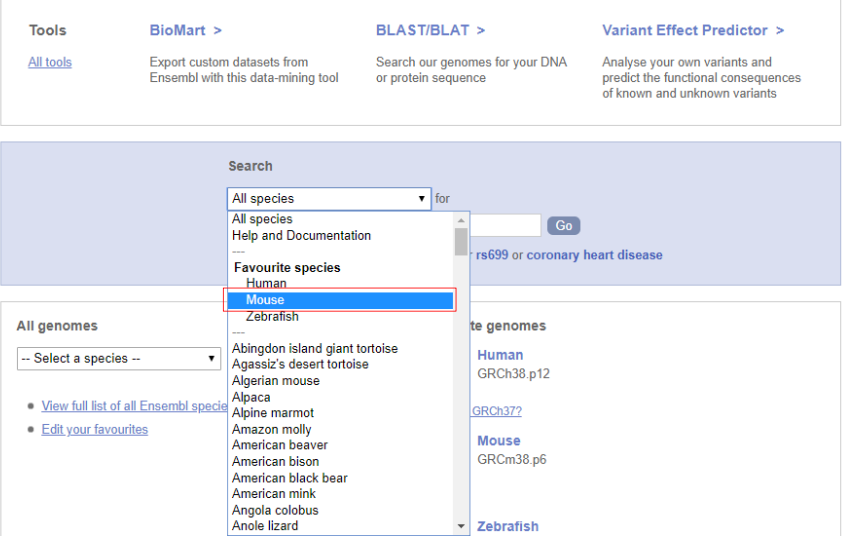

\section{C}

e Ensemb| вLASTRLAT | veP | Tools | Biomat | Downloads | Help \& Docs | Blog
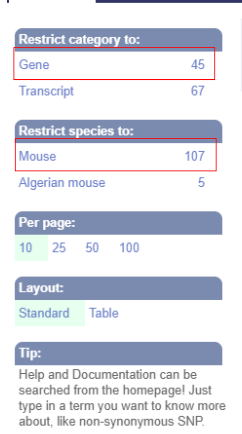

ROSA26

112 results match ROSA26

Did you mean... $\mathrm{V}$

Gt(ROSA)26Sor (Mouse Gene, Strain: reterence, (CL57BL6))

ENSMUSG00000086429 6:1113067428-113077333:-1

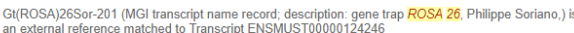
Variant table $\bullet$ Phenotypes $\bullet$ Location $\bullet$ Extemal Refs. Regulation $\bullet$ Orthologues $\cdot$ Gene tree

Gt(ROSA)26Sor-204 (Mouse Transcript. Strain: reference (CL57BL6))

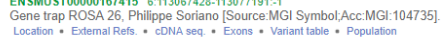
GtitROSA)26S0r-202 (Mouse Transcript, Strain: reference (CL.57BL6))

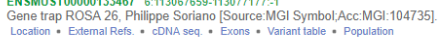
Gt(ROSA)26Sor-203 (Mouse Trans cript. Strain: reference (CL57BL6))

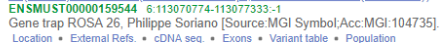
GttROSA)26S0r-201 (Mouse Transcript, Strain: reference (CL57BL6))

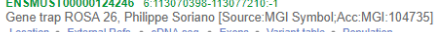
novel transcript (Mouse Transchipt, Strain: BALB/C)
B

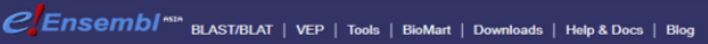

$\begin{array}{lll}\text { Tools } & \text { Biomart > } & \text { BLAST/BLAT > Variant Effect }\end{array}$

All took Export custom datasets from
Ensembl with this data-mining
tool

Predictor >

Analyse your own variants
and predict the functional consequences of known and

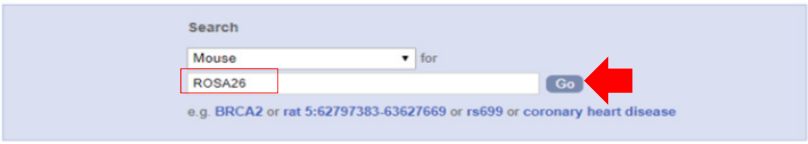

\section{All genomes}

- Select a species -

- Yiew full ist of all Ensembtopecies

- Edit vour favourites

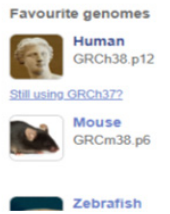

D

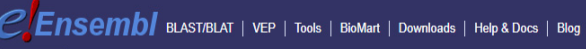
New Search
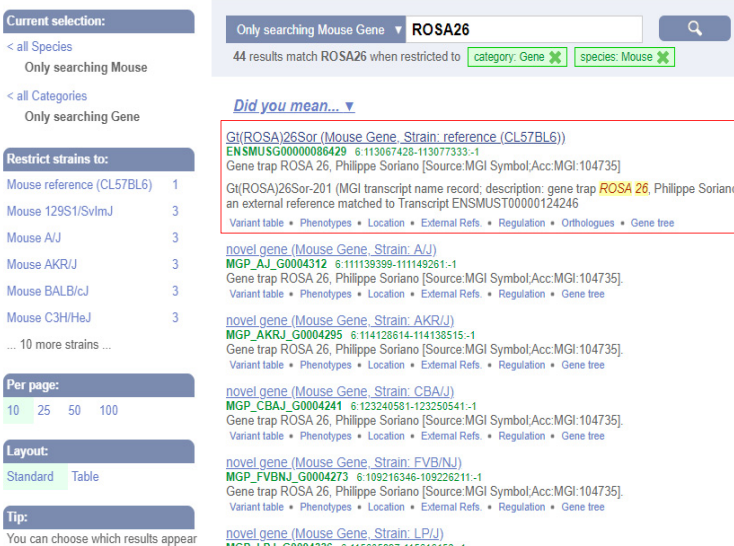

Did you mean... .

Gt(ROSA)26Sor (Mouse Gene, Strain: reference (CL57BL6))

Gene trap ROSA 26, Philippe Soriano [Source:MGI Symbol:Acc:MG1:104735] Gt(ROSA)26Sor-201 (MGI transcript name record, description: gene trap ROSA 26. Philippe Soriano, J

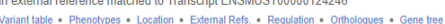

novel gene (Mouse Gene, Strain: A/J)

Gene trap ROSA26, Philippe Soriano Source:MGI Symbol;Acc MG1-10473

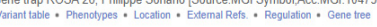

novelgene (Mouse Gene, Strain: AKR/J)

Gene trap ROSA 26. Philippe Soriano [Source:MGG Symbol:Acc:MGl:104735]

novel gene (Mouse Gene, Strain: CBAJ)

Gene trap ROSA 26, Phililppe Soriano [Source: MG ISymbol:Acc.MGl:10473.

novel gene (Mouse Gene, Strain: FVE/NJ)

Genent trap RŌOSA 26, Philippe Soriano [Source:MGI Symbol:Acc.MGI:104735]

novel gene (Mouse Gene, Strain: LP/J) 
bioRxiv preprint doi: https://doi.org/10.1101/2020.06.22.166017; this version posted June 23, 2020. The copyright holder for this preprint (which was not certified by peer review) is the author/funder, who has granted bioRxiv a license to display the preprint in perpetuity. It is made available under aCC-BY-NC-ND 4.0 International license.

\section{Supplementary Fig. 3}

A

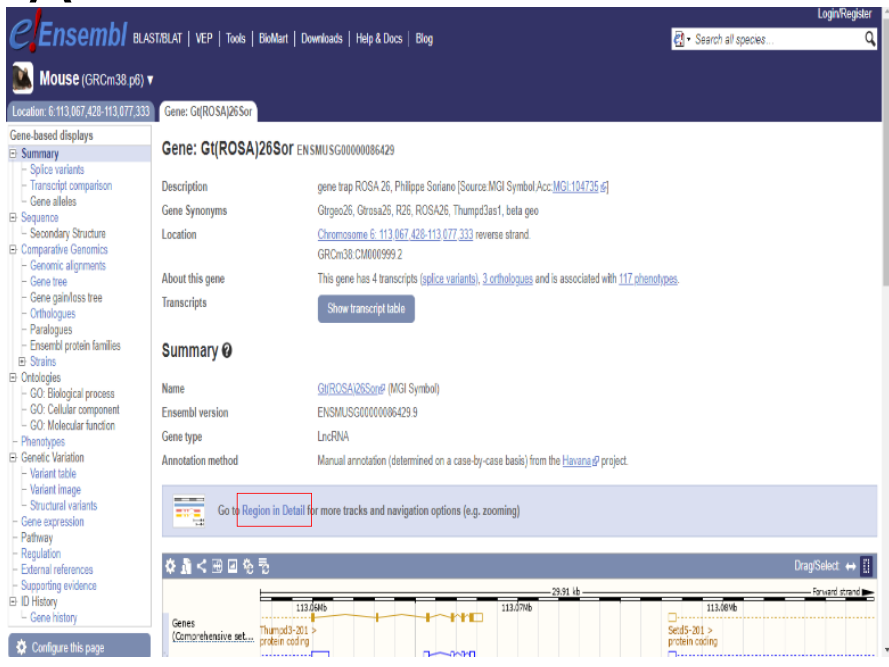

\section{C}

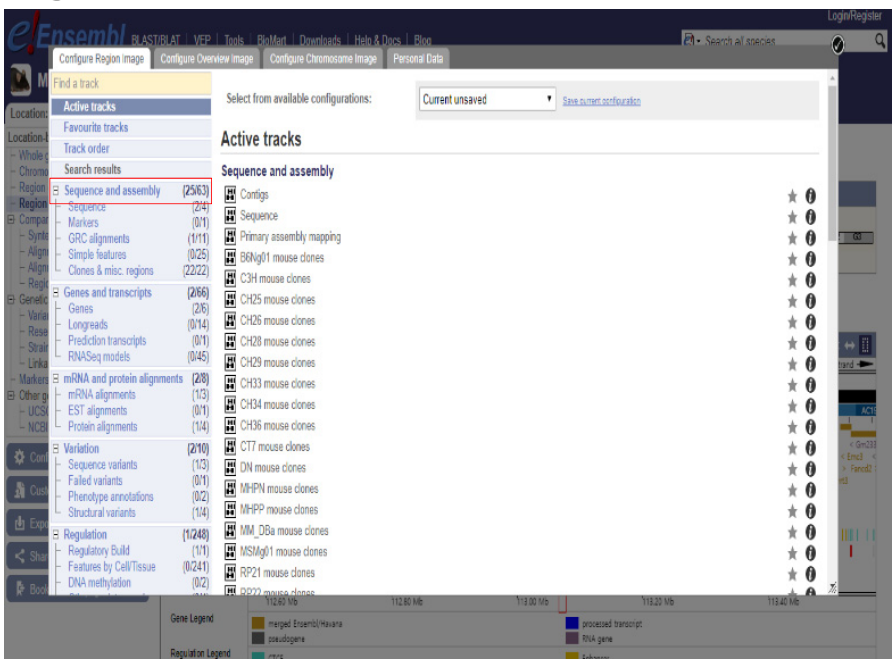

B

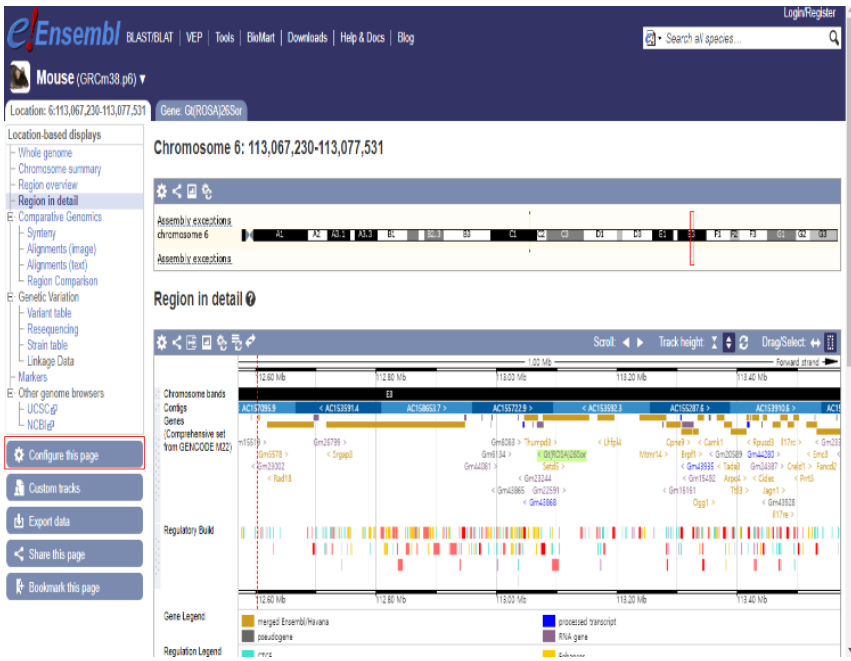

$\mathrm{D}$

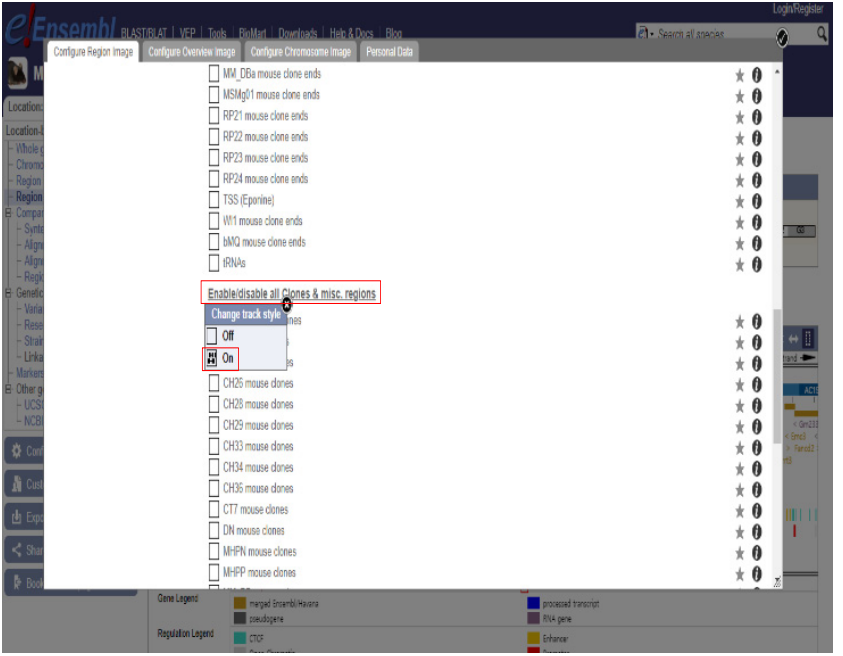


bioRxiv preprint doi: https://doi.org/10.1101/2020.06.22 166017; this version posted June 23, 2020. The copyright holder for this preprint (which was not certified by peer review) is the author/funder, who has granted bioRxiv a license to display the preprint in perpetuity. It is made available under aCC-BY-NC-ND 4.0 International license.

\section{Supplementary Fig. 4}
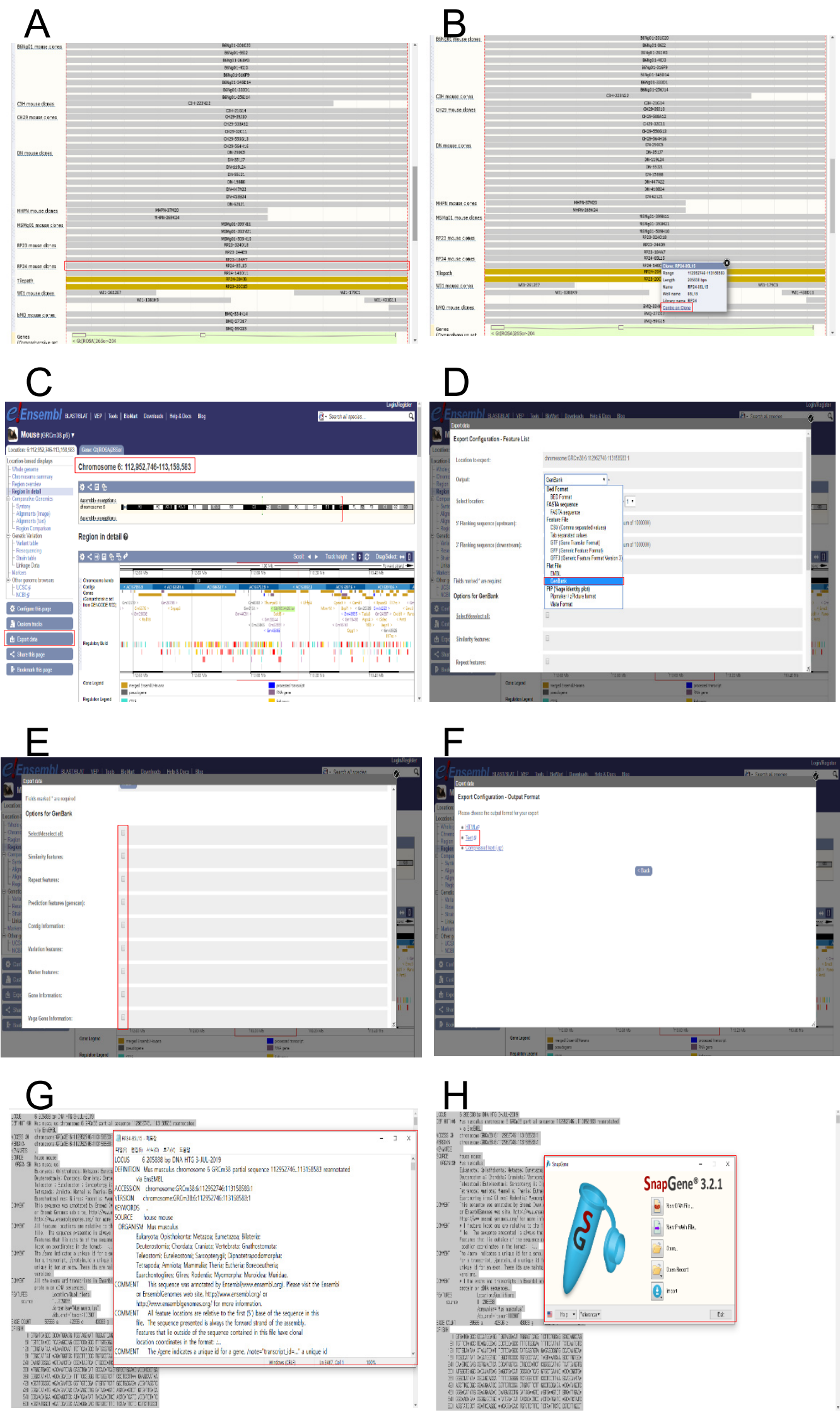
bioRxiv preprint doi: https://doi.org/10.1101/2020.06.22.166017; this version posted June 23, 2020. The copyright holder for this preprint (which was not certified by peer review) is the author/funder, who has granted bioRxiv a license to display the preprint in perpetuity. It is made available under aCC-BY-NC-ND 4.0 International license.

\section{Supplementary Fig. 5}

A

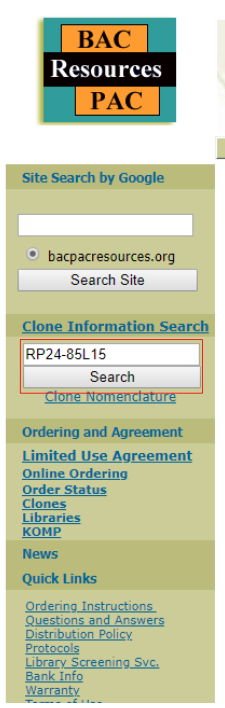

C

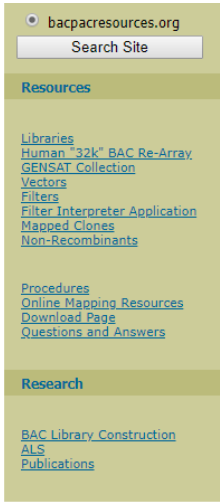

B
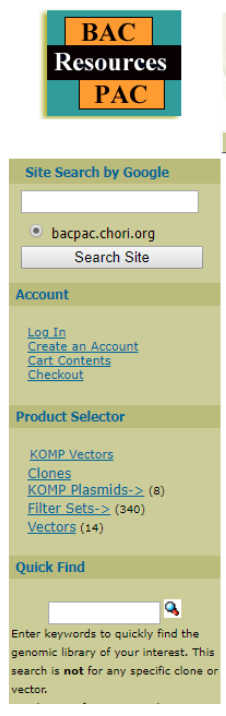

$\mathrm{C} \cdot \mathrm{H} \cdot \mathrm{O} \cdot \mathrm{R} \cdot \mathrm{I}$

Children's Hospital Oakland Research Institut

\begin{tabular}{l|l|l|l|l|} 
Home & Products & Resources & Online Ordering & About Us \\
\hline
\end{tabular}

Clone Information Search

Clone Information Search

\begin{tabular}{|l|l|l|l|}
\hline YOUR INPUT LIBRARY INFORMATION & ORDERING \& PRICING & AVAILABLE \\
\hline
\end{tabular}

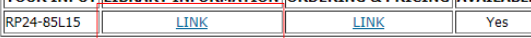

Add to Shopping Cart New Search generation, BAC modification, CRISPR/Cas9 and PiggyBac transposons). The primary objectives are to facilitate research projects by providing our expertise, allowing researchers to spend their efforts more productively. And yes, we will continue operating aA a nAC Srenice website un by academic researchers. We hope to have a separate bacpacresources,org with questions and suggestions for the kinds of services you are interested in.

PLEASE NOTE: OUR WEBSITE AND ONLINE ORDERING SYSTEM HAVE RECENTLY BEEN UPDATED TO PROVIDE INCREASED SECURITY. SOME ELEMENTS OF THE ONLIN PLEASE EMAIL TO BACPACORDERS@CHORI.ORG. ALSO, EMAIL ALL SCIENTIFIC QUESTIONS TO BACPAC@CHORI.ORG.

WHEN SEARCHING TO CHECK THE STATUS OF AN ORDER, USE THIS LINK

WHEN SEARCHING FOR AVAILABILITY OF [BAC] CLONES, PLEASE USE THE Clone Information Search link

For questions related to the site, please contact webmaster.
The use of this webste is subject to the terms of use.

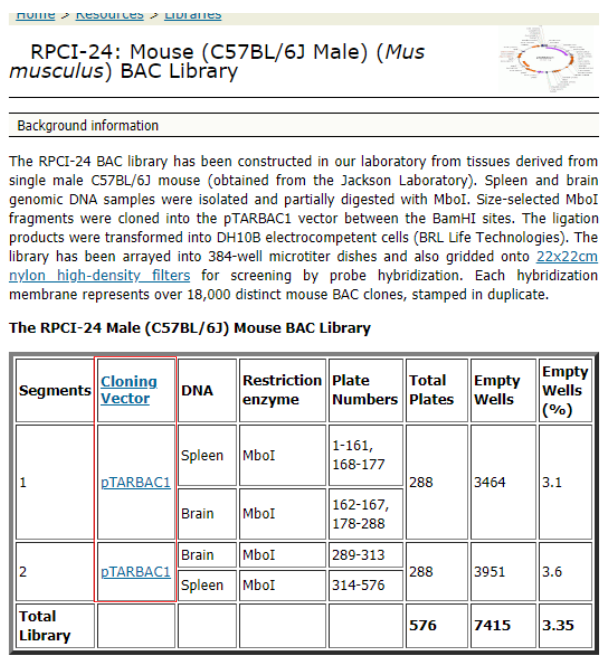

Г

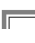


bioRxiv preprint doi: https://doi.org/10.1101/2020.06.22.166017; this version posted June 23, 2020. The copyright holder for this preprint (which was not certified by peer review) is the author/funder, who has granted bioRxiv a license to display the preprint in perpetuity. It is made available under aCC-BY-NC-ND 4.0 International license.

\section{Supplementary Fig. 6}

A

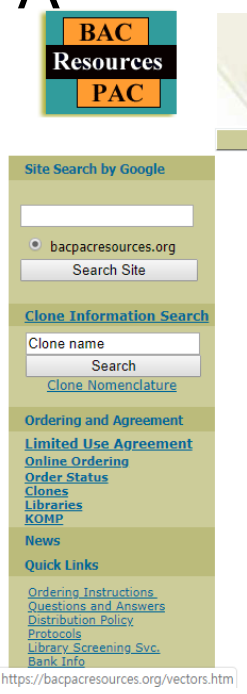

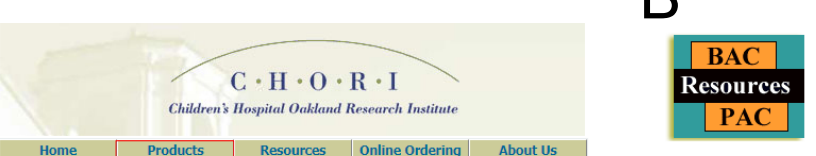

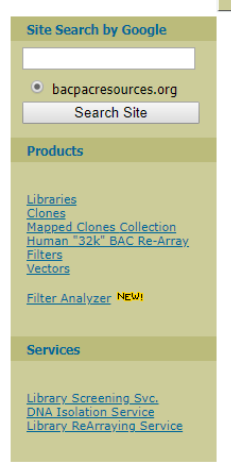

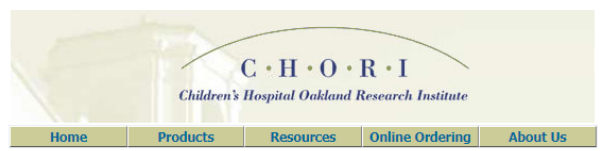

Home $>$ Products $>$ Vectors

Vectors information

Vectors used in our libraries can be obtained upon request. The 'Resources and Research' section of our website provides detailed map and sequence information about our vectors.

Ordering \& Pricing

All vectors are avaliable as Bacterial Stabs (DH10B) at the cost of $\$ 100$ plus an additional \$35 set-up fee. For shipping and general ordering details, please view the ordering \& pricing information page.

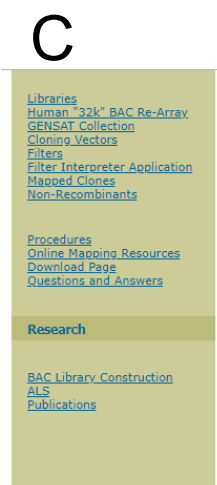

rou can tind in the tollowing a list of the ditterent vectors we use in our libranes, click on the links in the table to obtain a map or the sequence of these vectors.

\begin{tabular}{|c|c|c|c|}
\hline Graphics & Genbank Files & $\begin{array}{l}\text { Expandable } \\
\text { graphics }\end{array}$ & Comments \\
\hline $\begin{array}{l}\text { attiB-P[acman]-CmR- } \\
\text { BW }\end{array}$ & genbank file & & \\
\hline DBAC-lac & genbank file & & Not Available (BACPAC) \\
\hline DBACe3.6 & genbank file & & \\
\hline DBACGK1.1 & genbank file & & \\
\hline DBACGMR & genbank file & & \\
\hline DBAC-red & genbank file & & \\
\hline DCYPAC2 & genbank file & $\begin{array}{l}\text { Wmf picture } \\
\end{array}$ & \\
\hline DEpiFos5 & genbank file & & Order from Epicentre \\
\hline DCC1FOS & genbank file & & \\
\hline DCC1FOS-CHA & genbank file & & \\
\hline PPAC4 & genbank file & wemf picture & \\
\hline DTARBAC1 & genbank file & Wmf picture & \\
\hline DTARBAC1.3 & genbank file & wmf picture & \\
\hline PTARBAC2 & genbank file & wmf picture & \\
\hline DTARBAC2.1 & genbank file & \begin{tabular}{|l} 
Wmf picture \\
\end{tabular} & \\
\hline DTARBAC3 & genbank file & wemf picture & \\
\hline DTARBAC4 & genbank file & \begin{tabular}{|l} 
wmf picture \\
\end{tabular} & \\
\hline DTARBAC6 & genbank file & wmf picture & \\
\hline
\end{tabular}

The Genbank sequence files of the cloning vectors can be downloaded and read with standard text editors. The files contain all sequence information plus a standard feature table. The .Wmf picture format allows you to view and expand the vector image as you can be opened and printed using Microsoft Word. Informax offers a Freeware program for visualizing the molecular data of these vectors. Vector NTI Viewer is available for
For questions related to the site, please contact webmaster.
The use of this webste is subiest to the terms of use 